\title{
地上波デジタル放送の遅延プロファイル測定における時間分 解能向上のための複数チャネル連結方式に関する検討
}

\author{
Frequency Spectrum Connection Method for High Time-Resolution Delay \\ Profile Estimation in Digital Terrestrial Television Broadcasting
}

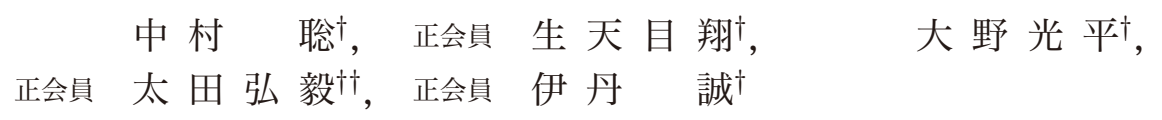

Akira Nakamura $^{\dagger}$, Sho Nabatame ${ }^{\dagger}$, Kohei Ohno $^{\dagger}$, Hiroki Ohta ${ }^{\dagger \dagger}$ and Makoto Itami ${ }^{\dagger}$

\begin{abstract}
In Japanese digital terrestrial television broadcasting (DTTB), the identification of multi-path is important to improve its reception characteristics. To enhance the resolution of the delay profile, connecting continuous multiple channels and the extended frequency bandwidth are effective. However, the guard band is existing between each channel and the transfer function is not obtained directly. The phases of each channel are not synchronized because the each channel is broadcasted independently. In this paper, a method to connect multiple channels is proposed. Interpolation of the guard band by using the liner adaptive predictor based on the RLS algorithm and compensation of phase between adjacent channels are performed. As a result, it is confirmed that resolution enhancement of the delay profile is possible. It is possible to improve the time resolution of the delay profile to below $0.024[\mu \mathrm{s}]$.
\end{abstract}

キーワード : OFDM, ISDB-T, DTTB, Multi-path, Delay Profile, RLS Algorithm, Channel Connection

\section{1.まえがき}

日本における地上波デジタルテレビジョン放送 (DTTB: Digital Terrestrial Television Broadcasting) は, ISDBT (Integrated Services Digital Broadcasting - Terrestrial $)^{12)}$ で規格化されており, 変調方式として OFDM (Orthogonal Frequency Division Multiplexing) が用いられて いる. 2012 年 4 月には DTTB に完全移行し放送が行われ ているが, サービスエリアにも関わらず現在でもテレビを 視聴しにくい難視エリアが存在している。難視の主な原因 として, 高層ビルによる遮蔽やマルチパス干渉などによる 受信電界強度の落ち込みが挙げられる。遮蔽やマルチパス の原因となる高層ビル群は年々増加しており, 難視エリア の問題は, より深刻化するものと予想される. また, ワンセ グメントサービスのように携帯端末を用いた受信では，送

2012 年 10 月 13 日受付, 2013 年 2 月 25 日最終受付, 2013 年 4 月 17 日 採録

†東京理科大学 基礎工学部 電子応用工学科

（广 125-0051 東京都葛飾区新宿 6-3-1, TEL 03-5876-1717)

†独立行政法人 情報通信研究機構 電磁波計測研究所 電磁環境研究室

（广 184-8795 東京都小金井市貫井北町 4-2-1，TEL 042-327-7429）

$\dagger$ Department of Applied Electronics, Tokyo University of Science (6-3-1 Nijyuku, Katsushika-ku, Tokyo, 125-0051, Japan)

$\dagger \dagger$ Electromagnetic Compatibility Laboratory, National institute of Information and Communications Technology

(4-2-1 Nukuikitamachi, Koganei-shi, Tokyo, 184-8795, Japan)
信局からの直接波が受信されることは稀であり，マルチパ スを多く受信することとなる。このような状況において難 視エリアの対策を行うには，まず反射物を特定するなどマ ルチパスの伝搬路の環境を詳細に解析・評価することが不 可欠となる.

ISDB-T の 1 チャネルの信号帯域幅は $5.57[\mathrm{MHz}]$ であり, パイロットシンボルから得られる遅延プロファイルの時間 分解能は，信号带域幅で決まり約 $0.1795[\mu \mathrm{s}]$ となる ${ }^{\left.3{ }^{4}\right)}$. 距 離分解能に換算すると約 $54[\mathrm{~m}]$ となる。マルチパスの各素 波の伝搬経路の詳細な解析や反射物の位置特定を行うには, 時間分解能の向上が求められる。そのための一つの手法と して, 一つの送信局から放送される複数チャネルの放送波 を用いて，周波数軸上で広带域な伝達特性を求め，高分解 能の遅延プロファイルを得ることにより，詳細な伝搬環境 を解析・評価する手法が提案・検討されている ${ }^{5) ~ 8)}$. これ らの手法では各チャネルごとに伝達特性を推定し，それら の伝達特性の位相や遅延時間を同一条件に補正し，補正し た伝達関数を用い連結を行っている，従来方式では, 各チャ ネルの伝達特性の位相や遅延時間のみを一致させ，高分解 能遅延プロファイルを求めている ${ }^{5) 6)}$. しかし，ガードバン ドの補間を行わず遅延プロファイルを求めた場合, 真の遅 延プロファイルとは異なったものが得られる。そこで，各 チャネルの伝達特性の位相や遅延時間を同一条件に補正し 
つつ，ガードバンド間の伝達特性を補間することにより，よ り精度の高い遅延プロファイルを得ることができると報告 されている ${ }^{8}$.

本論文では，上記の複数チャネルの連結による高分解能 遅延プロファイルを得るために，信号帯域外の伝達特性 を線形予測フィルタによって外挿し, 外挿された伝達特性 を利用した各チャネルの補正法を提案する。複数のチャネ ルを連結して一つの広带域な伝達特性として扱うために, RLS(Recursive Least Square) アルゴリズムに基づく線形 予測フィルタ 9) 11) により外挿された信号帯域外の伝達特 性の重なりを利用して, チャネル毎に生じる遅延時間差と 位相差について補正を行う。コンピュータシミュレーション において，ISDB-T に準拠した OFDM 信号を生成し，提 案方式による複数チャネルの連結の評価を行い複数チャネ ルの連結が可能であることを示す。また, 実フィールドの測 定データについて提案方式によるチャネル連結を行い, 高 分解能の遅延プロファイルを求め評価を行った.

本論文の構成は以下のようになっている。第 2 章では提 案方式である複数チャネルの連結の連結方法について述べ, 第 3 章では, 提案方式を用いた高分解能遅延プロファイル ついて求め評価する。第 4 章で本論文をまとめる.

\section{2. チャネル連結による遅延プロファイルの時間分 解能向上}

本章では, 複数チャネルの連結方法について述べる. 提案手法による高分解能な遅延プロファイルの導出法の ブロック図を図 1 に示す。

複数チャネルの連結では, まず各チャネルの伝達特性を推 定する必要がある。図 1 における “Channel Estimation” までの処理は各チャネルにおいてそれぞれ行う。各チャネ ルの伝達特性の推定は, 一般的な ISDB-T 受信機と同様に OFDM 信号に挿入されているスキャッタードパイロットシ ンボル 12)を用いて行う。

各チャネルは，非同期で放送されているためシンボル夕 イミングが異なる。また, 受信機側においても FFTウイ ンドウの先頭位置も異なるため, 遅延プロファイルの遅延 時間にずれが生じ，位相においても差が生じる。このため, 図 1 中の “Delay Time and Phase Compensation Using Extrapolated Transfer Function”において, 補正を行う チャネルを基準とするチャネルにシンボルタイミングが同 期するよう遅延時間差と位相差の補正を行う。遅延時間差 と位相差の補正では, 各チャネルにおいて外捙された伝達 特性の重なりを利用する。信号带域外の伝達特性は, 図 1 の “Extrapolation by Filter”において, 線形予測フィル 夕で外挿を行うことにより，求めることができる。信号帯 域外の外挿方法の詳細は, 2.1 節に示し, 遅延時間と位相 差の補正は, 2.2 節に示す.

図 1 “Channel Connection”において, ガードバンド を外挿し各チャネルの補正を行った伝達特性を周波数軸上
で連結する。連結する際，ガードバンドの補間は各チャネ ルにおいてガードバンドの中間まで外挿された伝達特性の みを用いることにより，外挿での誤差の軽減を図る，連結 を行った伝達特性を IDFT 処理することにより, 高分解能 な遅延プロファイル $h(t)$ が得られる。

\section{1 線形予測フィルタによる信号帯域外伝達特性の外挿}

本節では，各チャネルの低域側と高域側のガードバンド において，文献 9)～11) で報告されている RLS(Recursive Least Square) アルゴリズムに基づく線形予測フィルタを 用いた信号带域外の伝達特性の外挿方法について述べる.

RLS アルゴリズムに基づく線形予測フィルタを用いた 信号帯域外の伝達特性の外挿では, 線形予測係数ベクトル $\boldsymbol{w}(k)$ を学習する学習ステップとガードバンドの外挿を行 う外挿ステップに分けられる。

チャネル $l$ における $k$ 番目のスキャッタードパイロット シンボルから信号帯域内の伝達特性 $\hat{H}_{l}(0), \hat{H}_{l}(1), \ldots$, $\hat{H}_{l}\left(N_{c}-1\right)$ が推定される。ここで， $N_{c}$ は単一チャネルに おけるスキャッタードパイロットシンボルのサブキャリヤ総 数を表す。信号帯域外の伝達特性を外挿する場合, $\hat{H}_{l}(0)$, $\hat{H}_{l}(1), \ldots, \hat{H}_{l}\left(N_{c}-1\right)$ を入力として用いることにより帯域 外の伝達特性を外挿する。 $N_{\text {goal }}$ 番目までの伝達特性の外挿 を行った場合の外挿後の伝達特性は, $\bar{H}_{l}\left(N_{c}\right), \bar{H}_{l}\left(N_{c}+1\right)$, $\ldots, \bar{H}_{l}\left(N_{\text {goal }}-1\right)$ となる. 信号帯域外の伝達特性 $\bar{H}_{l}(k+L)$ の外挿を行う場合，以下の式により信号帯域外の伝達特性 $\bar{H}_{l}(k+L)$ を線形予測により外挿する.

$$
\bar{H}_{l}(k+L)=\boldsymbol{w}_{o p t}^{H} \boldsymbol{x}(k)
$$

ここで， $L$ は線形予測フィルタのタップ長を表し， $\boldsymbol{w}_{o p t}$ は 以降に述べる最適線形予測係数べクトルであり, $\boldsymbol{w}_{o p t}^{H}$ は, $\boldsymbol{w}_{\text {opt }}$ の共役転置を表す。 また, 線形予測フィル夕の係数べ クトル $\boldsymbol{w}(k)$ を次式で定義する.

$$
\boldsymbol{w}=\left[\begin{array}{llll}
w_{0} & w_{1} & \cdots & w_{L-1}
\end{array}\right]^{T}
$$

信号帯域外の外挿を行う場合， $k$ は， $N_{c}-L \leqq k<$ $N_{\text {goal }}-L$ となるスキャッタードパイロットシンボルのサ ブキャリヤ番号を表し，このときの入力ベクトル $\boldsymbol{x}(k)$ は 以下の式で表される。

$$
\begin{aligned}
& \boldsymbol{x}(k)=\left[\begin{array}{lll}
\bar{H}_{l}(k+L-1) & \bar{H}_{l}(k+L-2) & \cdots
\end{array}\right. \\
& \left.\begin{array}{llll}
\bar{H}_{l}\left(N_{c}\right) & \hat{H}_{l}\left(N_{c}-1\right) & \cdots & \hat{H}_{l}(k)
\end{array}\right]^{T}
\end{aligned}
$$

外挿ステップにおける $k$ は, $N_{c}-L \leqq k<N_{\text {goal }}-L$ の範 囲を表し， $N_{\text {goal }}-N_{c}$ 回外挿を繰り返すことにより，信号 帯域外の伝達特性の外挿を行う。信号帯域外での伝達特性の 外挿は, 最適線形予測係数べクトル $\boldsymbol{w}_{o p t}$ を用い, 伝達特性 $\bar{H}_{l}(k+L)$ を推定する。推定された伝達特性 $\bar{H}_{l}(k+L)$ を入力として用いることにより，信号带域外の伝達特性 $\bar{H}_{l}(k+L+1)$ を推定する. 外挿を行った伝達特性には, 予測誤差が含まれ信号帯域から離れれば離れるほど予測誤 


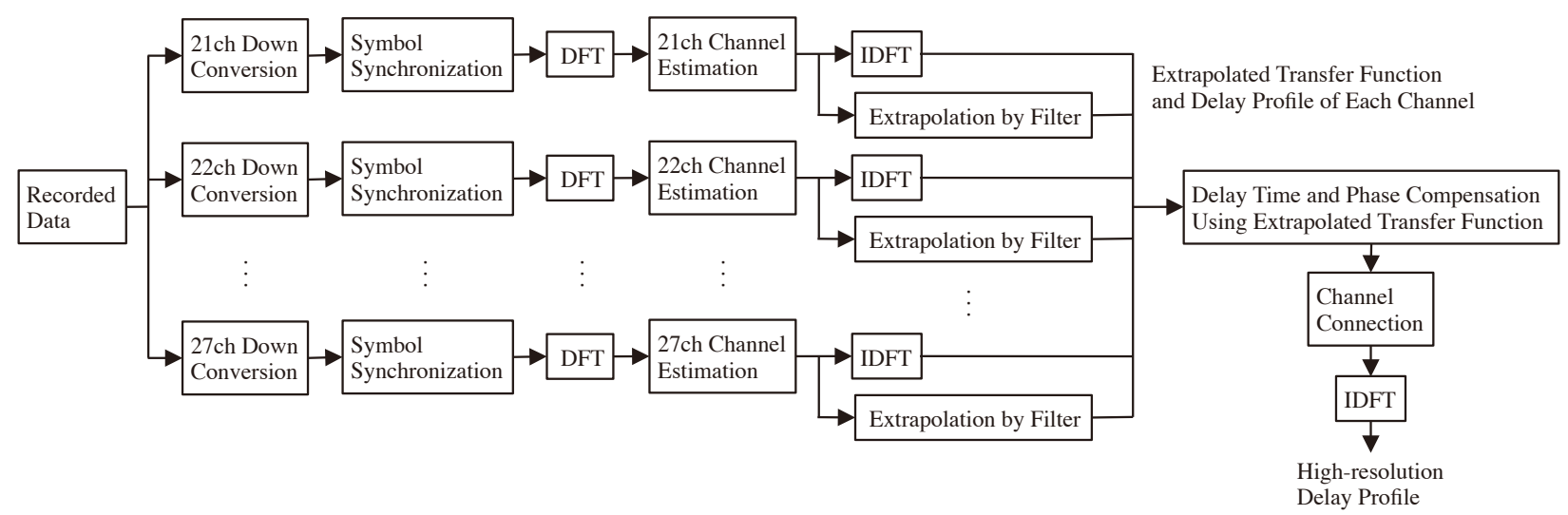

図 1 チャネル連結処理のブロック図

Block Diagram of Channel Connection.

差が増大するため，外挿された伝達特性は，信号帯域から 離れれば離れるほど劣化する。外挿ステップで用いられる 最適線形予測係数ベクトル $\boldsymbol{w}_{o p t}$ は, 以下に示す学習ステッ プにより求める.

線形予測フィルタの線形予測係数ベクトル $\boldsymbol{w}(k)$ は, ス キャッタードパイロットシンボルから推定されるサブキャ リヤの伝達特性 $\hat{H}_{l}(0), \hat{H}_{l}(1), \ldots, \hat{H}_{l}\left(N_{c}-1\right)$ を用い学 習を行う。線形予測係数ベクトル $\boldsymbol{w}(k)$ の学習では, 予測 誤差 $e(k)$ が 0 に近づくように繰り返し伝達特性の推定を行 う.このとき, 予測誤差 $e(k)$ は以下の式で表される.

$$
e(k)=\hat{H}_{l}(k+L)-\boldsymbol{w}^{H}(k-1) \boldsymbol{x}(k)
$$

ここで, 線形予測係数ベクトル $\boldsymbol{w}(k-1)$ と入力ベクトル $\boldsymbol{x}(k)$ は，以下の式で表される.

$\boldsymbol{w}(k-1)=\left[\begin{array}{lllll}w_{0}(k-1) & w_{1}(k-1) & \cdots & w_{L-1}(k-1)\end{array}\right]^{T}$

$$
\boldsymbol{x}(k)=\left[\begin{array}{lllll}
\hat{H}_{l}(k+L-1) & \hat{H}_{l}(k+L-2) & \cdots & \hat{H}_{l}(k)
\end{array}\right]^{T}
$$

線形予測フィルタの線形予測係数ベクトル $\boldsymbol{w}(k)$ の学習に は，RLS アルゴリズムを用いる。 RLS アルゴリズムでは, 線形予測係数ベクトル $\boldsymbol{w}(k)$ は, 予測誤差 $e(k)$ にしたがう て以下のように更新される。

$$
\boldsymbol{w}(k)=\boldsymbol{w}(k-1)+\boldsymbol{K}(k) e^{*}(k)
$$

線形予測係数ベクトル $\boldsymbol{w}(k)$ の更新は, $k=0$ から $k=$ $N_{c}-L-1$ まで $N_{c}-L$ 回行い, $\boldsymbol{w}\left(N_{c}-L-1\right)$ を得る. 得られた $\boldsymbol{w}\left(N_{c}-L-1\right)$ を(1) 式における $\boldsymbol{w}_{\text {opt }}$ として用 いることにより信号帯域外の伝達特性の外挿を行う。ここ で, 線形予測係数ベクトル $\boldsymbol{w}(k)$ の更新におけるカルマン ゲインベクトル $\boldsymbol{K}(k)$ と自己相関行列の逆行列 $\boldsymbol{P}(k)$ は次 式により更新される。

$$
\boldsymbol{K}(k)=\frac{\boldsymbol{P}(k-1) \boldsymbol{x}(k)}{\boldsymbol{x}^{H}(k) \boldsymbol{P}(k-1) \boldsymbol{x}(k)+\lambda}
$$

$$
\boldsymbol{P}(k)=\frac{\boldsymbol{P}(k-1)-\boldsymbol{K}(k) \boldsymbol{x}^{H}(k) \boldsymbol{P}(k-1)}{\lambda}
$$

ここで, $\lambda$ は忘却係数であり, 本論文では, $\lambda=0.99$ とし た ${ }^{9)}$. 自己相関行列の逆行列と線形予測係数ベクトルの初 期值 $\boldsymbol{P}(-1), \boldsymbol{w}(-1)$ は以下のように設定した.

$$
\begin{aligned}
& \boldsymbol{P}(-1)=\delta^{-1} \boldsymbol{I} \\
& \boldsymbol{w}(-1)=\mathbf{0}
\end{aligned}
$$

ただし，I は単位行列， $\delta$ は微少な正の実数であり，本論 文では $10^{-10}$ として線形予測係数べクトル $\boldsymbol{w}(k)$ の学習を 行う。

\section{2 遅延時間差と位相差の補正}

各送信局は，独立に非同期で OFDM 信号を放送してお り, 受信機側においても FFT ウインドウの先頭位置も異 なる。また，各チャネルごとに独立に順次測定した場合も 各チャネルは非同期で記録される。このため, シンボル夕 イミングがチャネル毎に異なり，チャネル間で遅延時間差 と位相差が生じる。したがって，各チャネルを周波数軸で 連結するためには遅延時間差と位相差の補正が必要となる。 本節では，基準とするチャネルと補正を行うチャネルの遅 延時間差と位相差の補正について述べる.

図 2 に隣接するチャネル $l, l+1$ のシンボルタイミング のずれを示す。隣接する二つのチャネルは, 独立に送信さ れているため, 各チャネルの有効シンボルの先頭 (Start of Effective Symbol of Channel $l, l+1)$ 位置が異なる. 基 準時刻 (Reference Time) から各チャネル有効シンボルの 先頭までの時間差はそれぞれ $T_{l}, T_{l+1}$ と表される。また， 各チャネルにおいて, 受信機の FFT ウインドウの先頭位 置も異るため, FFT ウインドウの先頭から各チャネルの有 効シンボルの先頭までの時間差をそれぞれ $\tau_{l}, \tau_{l+1}$ と表す.

このとき, チャネル $l$ の送信信号 $u_{l}(t)$ は以下のように表 される。

$$
u_{l}(t)=\Re\left[e^{j 2 \pi f_{c, l}\left(t-T_{l}\right)} \sum_{n=0}^{N_{s}-1} d_{l, n} e^{j 2 \pi n f_{0}\left(t-T_{l}\right)}\right]
$$




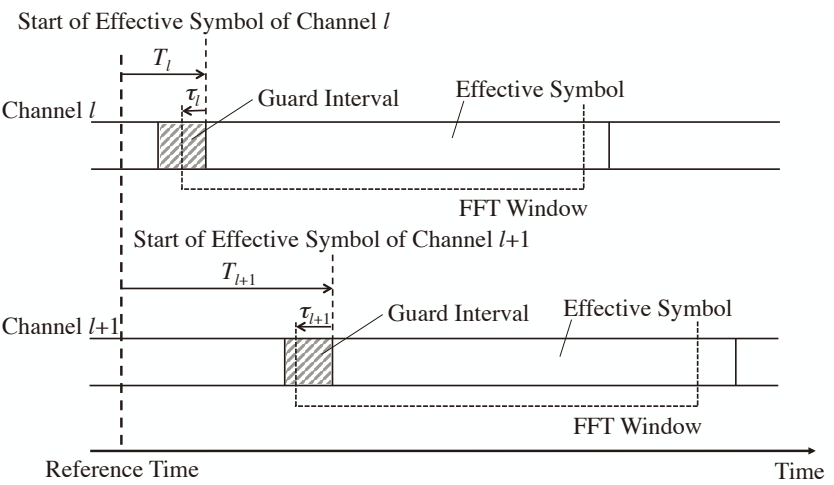

図 2 各送信局におけるシンボルタイミングのずれ Symbol Timing Gap of each Broadcasting Station.

ただし， $f_{c, l}, d_{l, n}$ は，それぞれチャネル $l$ における最も周 波数の低いサブキャリヤの搬送波周波数, サブキャリヤ $n$ における送信シンボルを表す。また， $f_{0}$ は，サブキャリヤ 間隔 $(992[\mathrm{kHz}])$ を表す。ここで, 基準時刻における伝送路 のインパルス応答を $h(\tau)$ とすると受信信号 $s_{l}(t)$ は以下の ように表される。

$$
\begin{aligned}
& s_{l}(t)=\int_{0}^{\infty} h(\tau) u(t-\tau) d \tau \\
&=\Re\left[e^{j 2 \pi f_{c, l}\left(t-T_{l}\right)} \sum_{n=0}^{N_{s}-1} d_{l, n} e^{j 2 \pi n f_{0}\left(t-T_{l}\right)}\right. \\
&\left.=\int_{0}^{\infty} h(\tau) e^{-j 2 \pi\left(f_{c, l}+n f_{0}\right) \tau} d \tau\right] \\
&\left.\sum_{n=0}^{j 2 \pi f_{c, l}\left(t-T_{l}\right)} d_{l, n} e^{j 2 \pi n f_{0}\left(t-T_{l}\right)} H\left(f_{c, l}+n f_{0}\right)\right]
\end{aligned}
$$

ただし, 基準時刻における伝達特性 $H(f)$ は以下の式で表 される。

$$
H(f)=\int_{-\infty}^{\infty} h(\tau) e^{-j 2 \pi f \tau} d \tau
$$

また, $s_{l}(t)$ のダウンコンバージョン後の信号 $r_{l}(t)$ は以下 の式のように表される.

$$
r_{l}(t)=e^{j \theta_{l}} \sum_{n=0}^{N_{s}-1} H\left(f_{c, l}+n f_{0}\right) d_{l, n} e^{j 2 \pi n f_{0}(t-\tau)}
$$

ここで，各チャネルは非同期のため搬送波の初期位相 $\theta_{l}$ が 異なる。受信機では, DFT処理を行うと $k$ 番目のサブキャ リヤは以下の式で表される。

$$
\hat{d}_{k, l}=\frac{1}{T} \int_{T_{l}-\tau_{l}}^{T+T_{l}-\tau_{l}} r_{l}(t) e^{-j 2 \pi k f_{0}\left(t+T_{l}-\tau_{l}\right)} d t
$$

ここで, $T$ は有効シンボル長を表し,$t=\xi+T_{l}-\tau_{l}$ と変 数変換を行うと以下の式で表される.

$$
\begin{aligned}
\hat{d}_{k, l} & =\frac{1}{T} \int_{0}^{T} r_{l}\left(\xi+T_{l}-\tau_{l}\right) e^{-j 2 \pi k f_{0} \xi} d \xi \\
& =e^{j \theta_{l}} \sum_{n=0}^{N_{s}-1} H\left(f_{c, l}+n f_{0}\right) d_{n, l} e^{-j 2 \pi n f_{0} \tau_{l}} \\
& \int_{0}^{T} e^{j 2 \pi(n-k) f_{0} \xi} d \xi \\
& =H\left(f_{c, l}+k f_{0}\right) e^{j \theta_{l}} e^{-j 2 \pi k f_{0} \tau_{l}} d_{n, l}
\end{aligned}
$$

同様に隣接するチャネル $l+1$ について, $k$ 番目のサブキャ リヤは以下の式で表される。

$$
\hat{d}_{k, l+1}=H\left(f_{c, l+1}+k f_{0}\right) e^{j \theta_{l+1}} e^{-j 2 \pi k f_{0} \tau_{l+1}} d_{n, l}
$$

したがつて, チャネル $l, l+1$ において $f_{c, l}+k f_{0}, f_{c, l+1}+$ $k f_{0}$ にそれぞれ対応する伝達特性 $H_{l}(k), H_{l+1}(k)$ は以下 の式で与えられる。

$$
H_{l}(k)=H\left(f_{c, l}+k f_{0}\right) e^{-j \theta_{l}} e^{-j 2 \pi k f_{0} \tau_{l}}
$$

$$
H_{l+1}(k)=H\left(f_{c, l+1}+k f_{0}\right) e^{-j \theta_{l+1}} e^{-j 2 \pi k f_{0} \tau_{l+1}}
$$

受信機ではこれらの值はスキャッタードパイロットシン ボルを用いて推定され， $k$ 番目のパイロットから推定され る伝送路特性を $\hat{H}_{l}(k)$ とすると，

$$
\begin{aligned}
\hat{H}_{l}(k) & =H_{l}\left(k L_{p}\right) \\
& =H\left(f_{c, l}+k L_{p} f_{0}\right) e^{-j \theta_{l}} e^{-j 2 \pi k L_{p} f_{0} \tau_{l}} \\
& =H\left(f_{c, l}+k f_{p}\right) e^{-j \theta_{l}} e^{-j 2 \pi k f_{p} \tau_{l}}
\end{aligned}
$$

ただし， $L_{p}$ は，周波数軸方向のパイロット間隔 $(3$ サブキャ リヤ) を表し， $f_{p}$ はスキャッタードパイロットシンボルが 挿入されているサブキャリヤ間隔 $\left(f_{p}=L_{p} \times f_{0}\right)$ を表して いる.ここで，隣接するチャネル $l, l+1$ に対して $\hat{H}_{l}(k)$, $\hat{H}_{l+1}(k)$ が得られたとする. 同一の送信点から同一シンボ ルタイミングで送信され，受信機において同一のタイミン グで受信されていれば $\theta_{l}=\theta_{l+1}, \tau_{l}=\tau_{l+1}$ となるが，実 際にはこれらの值は必ずしも等しくないため, 各チャネル で求められた伝達特性を連続的に配置することはできない. また，チャネル間にガードバンドが存在し，その範囲の伝 達特性はパイロットシンボルから直接求めることは不可能 である。

チャネル $l$ の伝達特性を用いて, 高域側のチャネル $l+1$ の信号帯域に $M$ パイロットシンボル分，チャネル $l+1$ の伝達特性を用いて低域側のチャネル $l$ の信号帯域に $M$ パイロットシンボル分外挿することによって，それぞれ $\bar{H}_{l}\left(f_{c, l}+k f_{p}\right) \quad\left(k=0, \cdots, N_{c}-1, \cdots, N_{c}+N_{g}-\right.$ $\left.1, \cdots, N_{c}+N_{g}+M-1\right), \bar{H}_{l+1}\left(f_{c, l+1}+m f_{p}\right)(m=$ $\left.-M-N_{g}+1, \cdots,-N_{g}+1, \cdots, 0, \ldots, N_{c}-1\right)$ の伝達特 性を得ることができる。仮に外挿が理想的に行われたと仮 定すると，以下の関係が成立する. 


$$
\begin{gathered}
\bar{H}_{l}\left(f_{c, l}+k f_{p}\right)=H\left(f_{c, l}+k f_{p}\right) e^{-j \theta_{l}} e^{-j 2 \pi k f_{p} \tau_{l}} \\
\left(k=0, \cdots, N_{c}-1, \cdots, N_{c}+N_{g}-1,\right. \\
\left.\cdots, N_{c}+N_{g}+M-1\right) \\
\bar{H}_{l+1}\left(f_{c, l+1}+k f_{p}\right)=H\left(f_{c, l+1}+k f_{p}\right) \\
e^{-j \theta_{l+1}} e^{-j 2 \pi k f_{p} \tau_{l+1}} \\
\left(k=-M-N_{g}+1, \cdots,-N_{g}+1,\right. \\
\left.\cdots, 0, \cdots, N_{c}-1\right)
\end{gathered}
$$

ここで, $f_{c, l+1}=f_{c, l}+\left(N_{c}+N_{g}\right) f_{p}$ が成立するため,

(23) 式は次の様に書き換えることができる.

$$
\begin{aligned}
\bar{H}_{l+1}\left(f_{c, l}+k f_{p}\right)= & \hat{H}_{l+1}\left(f_{c, l+1}+\left(k-N_{c}-N_{g}\right) f_{p}\right) \\
= & H\left(f_{c, l}+k f_{p}\right) e^{-j \theta_{l+1}} \\
& e^{-j 2 \pi\left(k-N_{c}-N_{g}\right) f_{p} \tau_{l+1}} \quad(24) \\
(k=- & M+N_{c}+1, \cdots, N_{c}+1, \cdots \\
& \left.N_{c}+N_{g}, \cdots, 2 N_{c}+N_{g}-1\right)
\end{aligned}
$$

このとき $\bar{H}_{l}\left(f_{c, l}+k f_{p}\right)$ と $\bar{H}_{l+1}\left(f_{c, l}+k f_{p}\right)$ は, $k=$ $N_{c}-M-1, \cdots, N_{c}+N_{g}+M-1$ の範囲において值が存在 し，同一の周波数に対応する伝送路特性に対応するため，理 想的には違いは $\theta_{l}, \theta_{l+1}, \tau_{l}, \tau_{l+1}$ によって生じる位相回転の みである.ここで, $N_{g}$ はガードバンドにおけるパイロット サブキャリヤ総数を表す．そこで, $\bar{H}_{l}$ を基準とし， $\bar{H}_{l+1}$ の 位相回転を補正し, $k=N_{c}-M-1, \cdots, N_{c}+N_{g}+M-1$ の範囲で両者の特性ができるだけ重なるようにする。これ によって独立した二つのチャネルから得られた隣接する伝 送路特性を連続的に接続できることが期待される。

$\bar{H}_{l}$ に対する $\bar{H}_{l+1}$ の位相回転量は以下の式で表される。

$$
\begin{aligned}
\Theta_{l+1}(k)= & \arg \left\{\bar{H}_{l}\left(f_{c, l}+k f_{p}\right) \bar{H}_{l+1}^{*}\left(f_{c, l}+k f_{p}\right)\right\} \\
= & \theta_{l-1}-\theta_{l}-2 \pi\left(N_{p}+N_{g}\right) f_{p} \tau_{l+1} \\
& +2 \pi k f_{p}\left(\tau_{l+1}-\tau_{l}\right) \quad(\bmod 2 \pi)
\end{aligned}
$$

$(25)$ 式より位相回転量 $\Theta_{l+1}(k)$ は $k$ に関しての 1 次関数 となるため, 傾きと切片が得られれば各周波数に対して位相 の補正を行うことができる. 本論文では傾きと切片を回帰直 線によって求める. $k=N_{c}-M-1, \cdots, N_{c}+N_{g}+M-1$ の範囲における位相回転量 $\Theta_{l+1}(k)$ を計算し, 直線を当て はめ傾きおよび切片を求め, それによってチャネル $l+1$ の 位相補正を行う。直線を当てはめるに当たって, (25) 式の值 の範囲は $-\pi$ から $\pi$ の範囲に制限されているため, 傾きが 大きくなりすぎると位相飛びが頻繁に生じ適切に当てはめ るのが困難になる。 そこで, あらかじめサンプリングタイミ ングの調整を行うことで, 遅延時間差 $\tau_{l+1}-\tau_{l}$ の值を大ま かに補正した後に回帰分析を行う。これによって位相飛びの 影響を減らし，より良い近似ができると考えられる。具体的
なサンプリングタイミングの調整方法は次の段落で述べる. 回帰直線によって切片 $\beta_{l}=\theta_{l-1}-\theta_{l}-2 \pi\left(N_{p}+N_{g}\right) f_{p} \tau_{l+1}$, および，傾き $\alpha=2 \pi k f_{p}\left(\tau_{l+1}-\tau_{l}\right)$ が得られれば,

$$
\bar{H}_{l+1}\left(f_{c, l}+k f_{p}\right) e^{j\left(\beta_{l}+k \alpha\right)}
$$

によって位相を補正した伝達特性が得られる。また，伝達 特性の重なりを利用した回帰直線による補正では, 伝送路 が時間的に変動しない場合, 伝達特性を時間的に平均する ことにより雑音を抑え CNR(Carrier to Noise Ratio)を上 げることができるため，伝達特性が低くなる場合において も補正することが可能であると考えられる。

大まかな遅延時間差 $\tau_{l+1}-\tau_{l}$ の補正では, 伝達特性を逆 フーリエ変換して得られる遅延プロファイルの相互相関を とることで基準とするチャネルとの遅延時間差 $\tau_{l+1}-\tau_{l}$ の 補正量を求める. 相互相関において, 相関出力 $c(p)$, 補正 する離散時間量 $p$, 基準とするチャネル $l$, 補正を行うチャ ネル $l+1$ とすると, 相関関数は次式のようになる ${ }^{12)}$.

$$
c(p)=\sum_{n_{d}=0}^{C_{R} N_{d}-1} \hat{h}_{l}\left(\frac{n_{d}}{C_{R}}\right) \hat{h}_{l+1}^{*}\left(\frac{n_{d}+p}{C_{R}}\right)
$$

ここで, $N_{d}$ は，単一チャネルにおける遅延プロファイルの 総サンプル数, $C_{R}$ は, 遅延プロファイルの分解能の向上 係数を表し， $C_{R}$ 倍にオーバサンプリングされた遅延プロ ファイルが得られる。 また, $C_{R}$ 倍にオーバサンプリング された $\hat{h}_{l}\left(n_{d} / C_{R}\right), \hat{h}_{l+1}\left(n_{d} / C_{R}\right)$ は以下の式で表される.

$$
\begin{aligned}
& \hat{h}_{l}\left(\frac{n_{d}}{C_{R}}\right)=\frac{1}{N_{c}} \sum_{k=0}^{N_{c}-1} \hat{H}_{l}(k) e^{j \frac{2 \pi k}{N_{c}} \cdot \frac{n_{d}}{C_{R}}} \\
& \hat{h}_{l+1}\left(\frac{n_{d}}{C_{R}}\right)=\frac{1}{N_{c}} \sum_{k=0}^{N_{c}-1} \hat{H}_{l+1}(k) e^{j \frac{2 \pi k}{N_{c}} \cdot \frac{n_{d}}{C_{R}}}
\end{aligned}
$$

$n_{d} / C_{R}$ により, 遅延プロファイルのサンプル点を補間し， 仮想的に分解能を向上させることができ，サイドローブま で解析を行うことができる。 また，(28)，(29) 式は図 1 に おける IDFT に相当する，大まかな遅延時間差を推定する 場合， $|c(p)|$ が最大となるような離散遅延時間量 $p_{\max }$ を求 める。求めら机た離散遅延時間量 $p_{\max }$ を用い $(25)$ 式にお いて，逆位相を乗算することにより補正を行う，大まかに 補正を行った後, 回帰分析を行い詳細な補正を行う.

図 5 に周波数に対する位相回転量 $\Theta_{l+1}(k)$ の例を表す. 図 5 に打いて * *゙パイロットシンボルから求めた位相差の プロット点, 直線は, プロット点から最小二乗法で求めた 回帰直線を表す，求めた回帰直線より，遅延時間差の補正 残差 $\alpha$, およびチャネル固有の位相差 $\theta_{l}$ を求め補正を行う.

以上のように隣接 2 チャネルに対して伝達特性を外挿し, 外挿された伝達特性の重なりを利用して位相補正を行うこ とによって，位相が連続しガードバンド部分が補間された 広帯域の伝達特性を得ることができる。本論文では，低带 域のチャネル $l$ から 外挿した特性はガードバンドの低带域 
側半分の伝達特性として用い，高帯域チャネル $l+1$ から 外挿した特性はガードバンドの高帯域側半分の伝達特性と して使用する。

連結を行う各チャネルの遅延時間差と位相差の補正は，図 6 に示すように，24 チャネルを基準チャネルとして隣接す る二つのチャネル (23 チャネル, 25 チャネル)から行う. 基 準とする 24 チャネルに対して補正された 23 チャネルと 25 チャネルを用いて，22 チャネルと 26 チャネルの補正を行 う。このようにして，隣接するチャネルの補正を行い，連 結を図る全てのチャネルの遅延時間差と位相差を補正する. 位相補正を複数の隣接チャネルで繰り返すことで, 独立の チャネルの特性を連結して広帯域な伝達特性を得ることが できる。広帯域な伝達特性を用いることで時間分解能の向 上した遅延プロファイルを得ることができる.

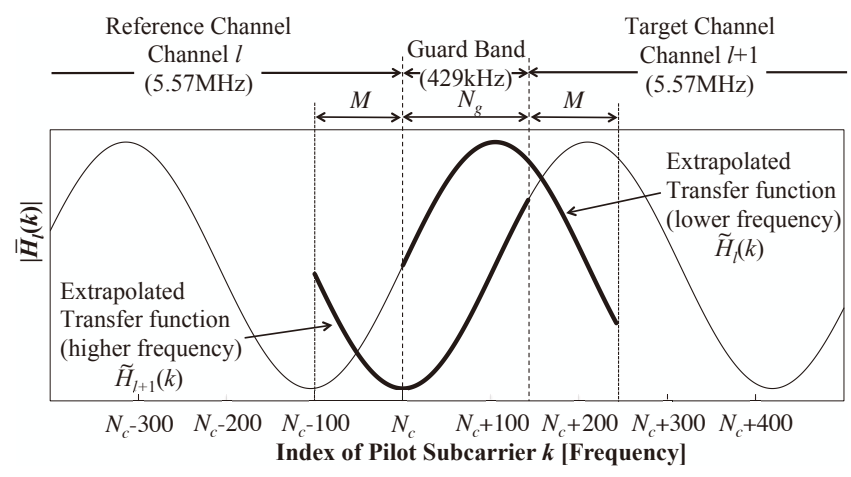

図 3 位相補正の概念図

Model of Phase Compensation.

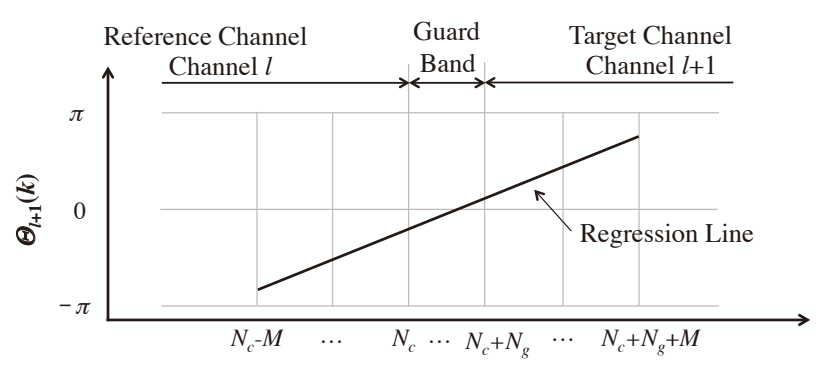

Index of Pilot Subcarrier $k$ [Frequency]

図 4 位相誤差推定の概念図

Model of Estimation of Phase Error.

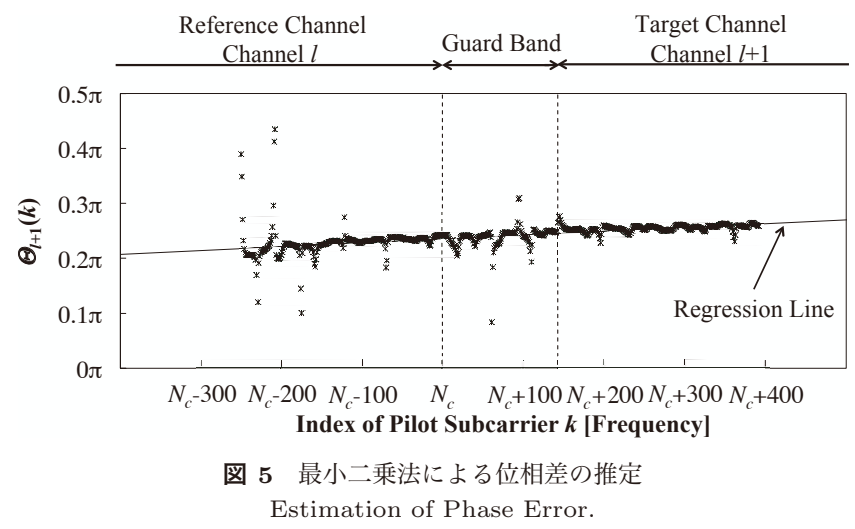

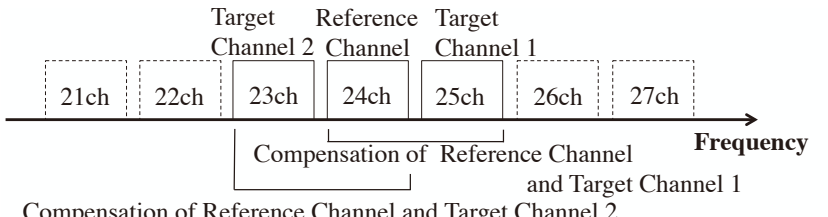

Compensation of Reference Channel and Target Channel 2

\begin{tabular}{|c|c|c|c|c|c|c|c|}
\hline & $\begin{array}{l}\text { Target } \\
\text { Channel } 4\end{array}$ & $\begin{array}{l}\text { eference } \\
\text { Channel }\end{array}$ & & $\begin{array}{l}\text { Reference } \\
\text { Channel }\end{array}$ & $\begin{array}{l}\text { Target } \\
\text { Channel }\end{array}$ & & \\
\hline $21 \mathrm{ch}$ & $22 \mathrm{ch}$ & $23 \mathrm{ch}$ & $24 \mathrm{ch}$ & $25 \mathrm{ch}$ & $26 \mathrm{ch}$ & $27 \mathrm{ch}$ & \\
\hline & $\begin{array}{l}\text { Compens } \\
\text { Reference } \\
\text { and Targe }\end{array}$ & $\begin{array}{l}\text { Ion of } \\
\text { Channel } \\
\text { Channel }\end{array}$ & & $\begin{array}{l}\text { Compen } \\
\text { Referen } \\
\text { and Targ }\end{array}$ & $\begin{array}{l}\text { sation of } \\
\text { ee Channe } \\
\text { et Chann }\end{array}$ & & Frequency \\
\hline $\begin{array}{l}\text { Target } \\
\text { Channel } 6\end{array}$ & $\begin{array}{r}\text { Referenc } \\
\text { Channe }\end{array}$ & & & & $\begin{array}{l}\text { eference } \\
\text { Channel }\end{array}$ & $\begin{array}{l}\text { Target } \\
\text { Channe }\end{array}$ & \\
\hline $21 \mathrm{ch}$ & $22 \mathrm{ch}$ & $23 \mathrm{ch}$ & $24 \mathrm{ch}$ & $25 \mathrm{ch}$ & $26 \mathrm{ch}$ & $27 \mathrm{ch}$ & \\
\hline
\end{tabular}

Reference Channel and Target Channel 6 Reference Channel and Target Channel 5

図 6 遅延時間差と位相差の補正順番

Sequence of Compensation of Delay Time Error and Phase Error.

\section{3. チャネル連結結果}

本章では, シミュレーションによるチャネル連結の評価 を行う。また，実フィールドによる測定データのチャネル 連結について述べる。

\section{1 シミュレーション}

本節では，シミュレーションによりチャネル連結の時間 分解能の結果を示す.

（1）シミュレーション諸元

本論文では通常，放送に用いられている ISDB-T:Mode3 1)2）を想定したシミュレーションを行った。東京タワーか らの放送を仮定し, 単一チャネル $5.57[\mathrm{MHz}]$ の放送波を, 独立に非同期で $7 \mathrm{ch}$ 分生成した。伝送路は，表 1 に示すマ ルチパス伝送路モデルを仮定している。また，各チャネル の遅延時間差と位相差は表 2 に示す。第 1，2，3 到来波は 単一チャネルの遅延プロファイルの分解能 $0.1795[\mu \mathrm{s}]$ 以下 で到来している。このときの伝達特性を図 7 に示す。(28), (29) 式について, $C_{R}=20$ として, 通常の IDFT に対し て 20 倍のサンプル点 $(1873 \times 20=37460$ 点) を持つ遅延 プロファイルを求め, (27) 式の相互相関により遅延時間差 を補正した。また，詳細な遅延時間差と位相差の補正では， (22), (23) 式について $M=288$ とし，ガードバンドの 5 倍となる帯域幅で回帰分析を行った。各チャネル間のガー ドバンド $(429[\mathrm{kHz}])$ を補間し 7 チャネル連結後の伝達特 性の帯域幅は, 単一チャネルの約 7.5 倍の $41.571[\mathrm{MHz}](=$ $5.571[\mathrm{MHz}] \times 7+429[\mathrm{kHz}] \times 6)$ になる．本論文では，パイ ロットシンボルから推定された $3 \times f_{0}(=2.979[\mathrm{kHz}])$ ごと に存在する伝達特性を逆フーリエ変換し遅延プロファイル を求めているため, 遅延プロファイルの時間分解能は得ら れた伝達特性の帯域幅 $\left(3 \times f_{0} \times N_{c}(=5.57[\mathrm{MHz}])\right)$ によつ て決まる。 


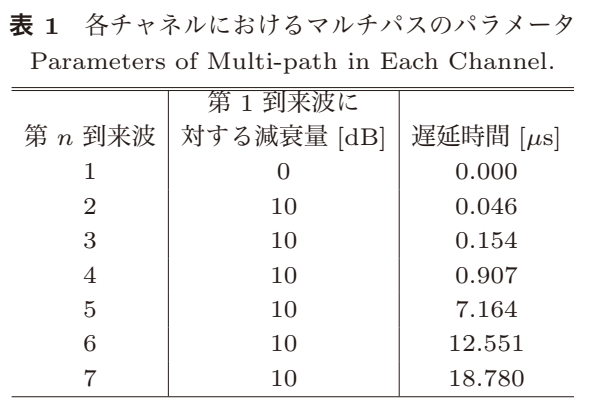

表 2 各チャネルの遅延時間差と位相差 Parameters of Delay Time and Phase of Each Channel. \begin{tabular}{l|l|l}
\hline \hline チャネル $l$ & 遅延時間差 $\tau_{l}[\mu \mathrm{s}]$ & 位相差 $\theta_{l}[\mathrm{rad}]$
\end{tabular}

\begin{tabular}{l|c|c}
21 & 7.690 & $0.3 \pi$ \\
22 & -0.338 & $-0.2 \pi$ \\
23 & 0.138 & $-0.7 \pi$ \\
24 & 0.000 & 0.0 \\
25 & -0.508 & $0.4 \pi$ \\
26 & 0.784 & $0.5 \pi$ \\
27 & -11.951 & $-0.1 \pi$ \\
\hline
\end{tabular}

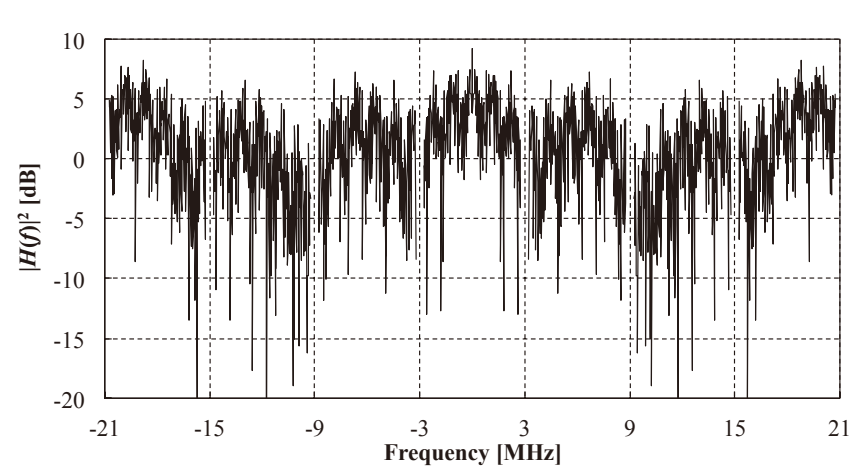

図 7 マルチパス伝送路の伝達特性

Transfer Function under Multi-path Model.

（2）シミュレーションによるチャネル連結結果

図 8 に CNR を変化させたときのタップ長に対する RMSE(Root Mean Square Error) を示す.ここで, RMSE は以下のように定義した。

$$
R M S E=\sqrt{\frac{\sum_{n=0}^{N_{a}-1}\{h(n)-\bar{h}(n)\}^{2}}{\sum_{n=0}^{N_{a}-1} h^{2}(n)}}
$$

$h(n)$ は理想的な遅延プロファイル, $\bar{h}(n)$ は位相差補正を 行い連結を行った伝達特性 $\bar{H}(n)$ をフーリエ変換し得られ た遅延プロファイルを表す。また， $N_{a}$ は，7 チャネル連結 後の遅延プロファイルの総サンプル数を表す. $h(n)$ と $\bar{h}(n)$ が近ければ RMSE は 0 に近づく.

図 8 より, タップ長 $L=150 \sim 350$ のとき, RMSE は上 昇し, タップ長 $L=250 \sim 300$ のとき, RMSE は最大とな る. その後, タップ長 $L$ が長くなるに従い RMSE は減少す る.これは, 第 4 到来波のフェージング周期 $(0.756[\mathrm{MHz}])$ とタップ長 $(3 \times 992 \times 254=0.756[\mathrm{MHz}])$ が一致するこ とにより引き起こされると考えられる。また，タップ長を 長くすることにより，RMSE は減少する。
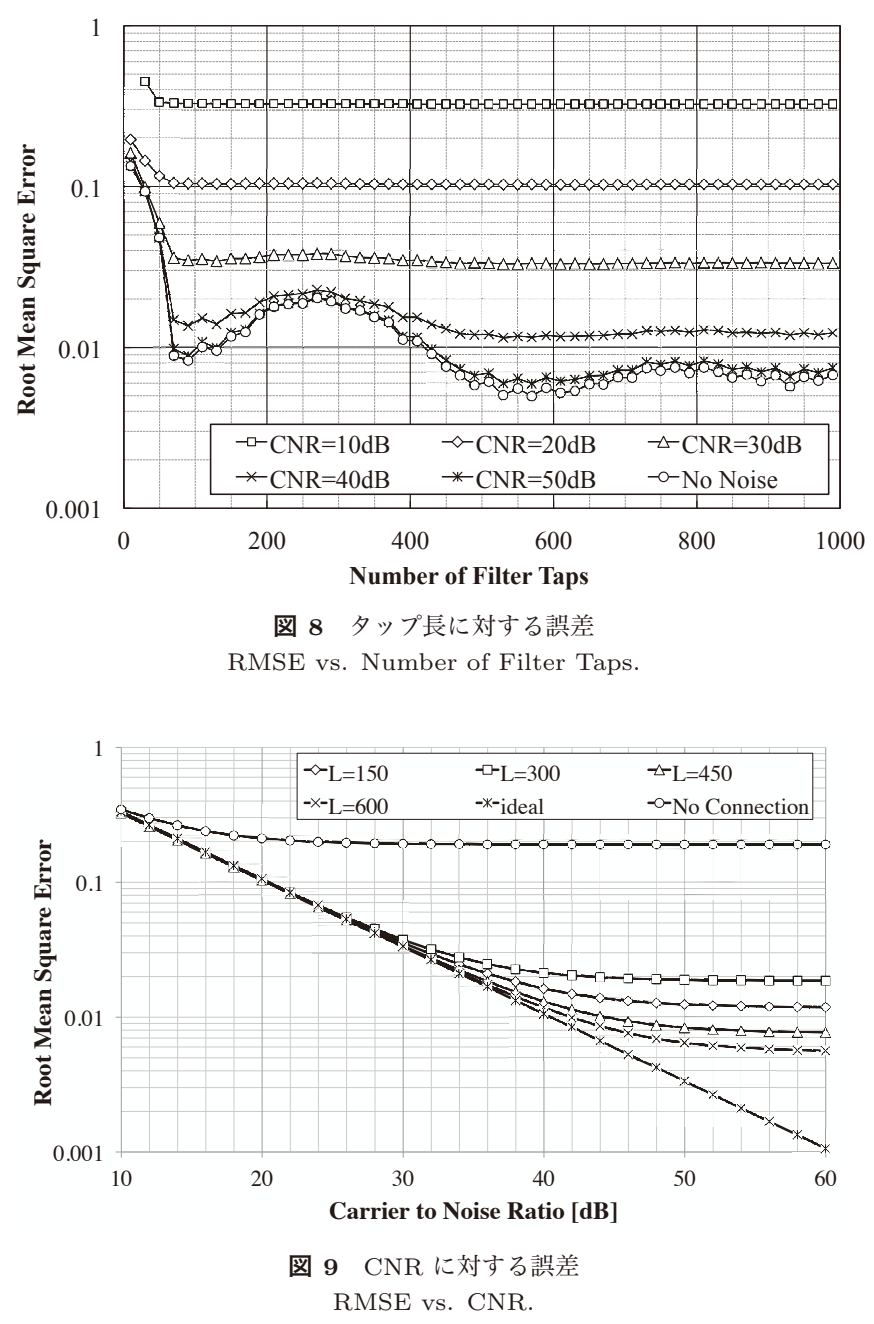

図 9 にタップ長 $L$ を変化させたときの CNR に対する RMSE を示す。図中の“Ideal”は，ガードバンドにおい てもパイロットシンボルが扱入されていると仮定し広带域 の伝達特性を推定した場合の RMSE を表す。また, “No Connection”は, 各チャネルにおいてパイロットシンボル から伝達特性を推定し各チャネル間の遅延時間差と位相差 のみを補正した場合の RMSE を示しており, ガードバン ドの補間は行っていない.

図 9 より, 表 1,2 に示したマルチパス環境下において, ガードバンドの補間を行った場合，ガードバンドの補間を 行わない場合に比べ，RMSEが低減することがわかる。ま た，タップ長 $L$ を 600 とすると, RMSEが 0.01 以下にな り非常に良い特性が得られたため, 以降は, タップ長を 600 として，チャネル連結を行い特性を評価した。

図 10，11，12，13 に提案方式による 7 チャネル連結後 の遅延プロファイルを示し, Relative Power[dB] は, 表 1 における第 1 到来波を $0[\mathrm{~dB}]$ とした場合の相対電力 $[\mathrm{dB}]$ を 表している.

図 10 は，2.2 節で述べた位相補正と遅延時間差の補正に おいて, (27) 式の相関関数を用いて大まかな補正を行った 場合の遅延プロファイルと, 伝達特性の重なりから回帰直 線を求め補正を行った場合の遅延プロファイルを示し, 図 


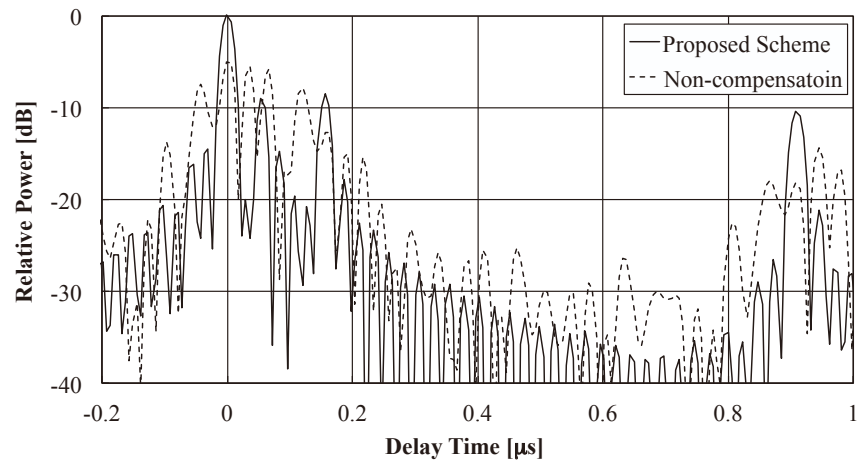

図 10 伝達特性の遅延時間および位相補正による遅延プロファ イルの誤差軽減

Delay Profile after Compensation of Phase and Delay Time.

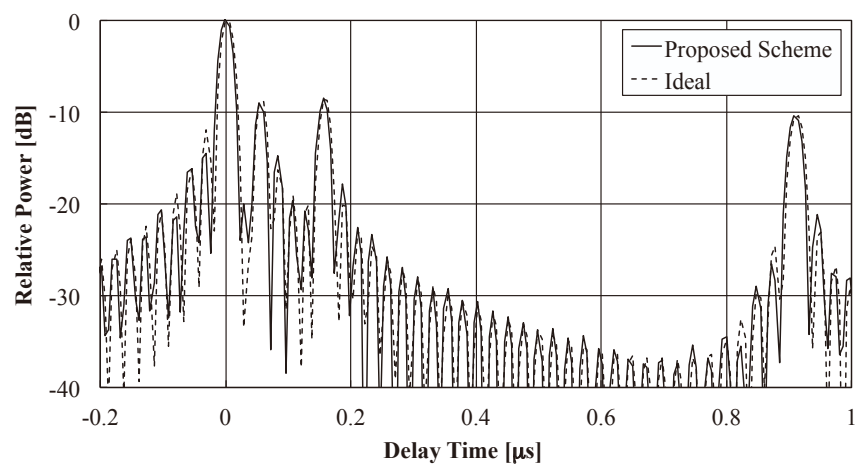

図 11 提案方式と理想遅延プロファイルの比較

Comparison between ideal Delay Profile and Proposed Scheme After Compensation of Phase and Delay Time.

中の “Proposed Scheme” は，相関関数と回帰直線を用い た場合を表し，“Non-compensation”は，相関関数のみ用 い大まかに補正した場合を表す。相関関数のみを用いた場 合，正しいパスを得ることができない，図 11 は，チャネル 連結後の遅延プロファイルを表しており，図中の “Ideal” は連結を図る帯域の伝達特性が理想的に得られた場合の遅 延プロファイルを表す。図 11 より，提案方式を用いること により, より精度の高い遅延プロファイルが得られ, 提案方 式では理想的な遅延プロファイルと同一の遅延プロファイ ルを得ることが可能である. 図 12 は, チャネル連結を行っ た場合と単一チャネルのみ用い求めた遅延プロファイルを 示し, 図 13 は拡大図を示す。図 12,13 より, 単一千ャネ ルから求めた遅延プロファイルでは，表 1 に示すパスが存 在しているはずだが，分解能以下で到来した 3 つ伝搬パス が混ざり合ってしまっている。一方，チャネル連結を行っ た遅延プロファイルでは, 単一チャネルでは分解不可能な 遅延時間差で到来した伝搬パスを解析することができる。

\section{2 実フィールドにおける測定データの解析}

本節では，提案方式を用いた実フィールドによる測定と 測定データの解析結果について述べる.

(1) 測定システム

図 14 に，測定システムのブロック図を示す。本論文で用 いた測定システムは，図中の“PC”を用いることで“Airwaves Recorder”の操作を行うことができる。“Airwaves

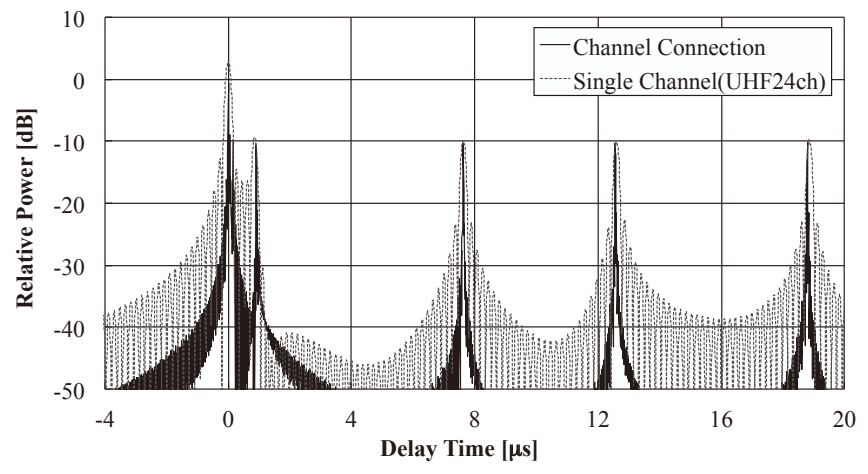

図 12 シミュレーションにおけるチャネル連結後の遅延プロ ファイル

Delay Profile After Performing Channel Connection using Simulated Data.

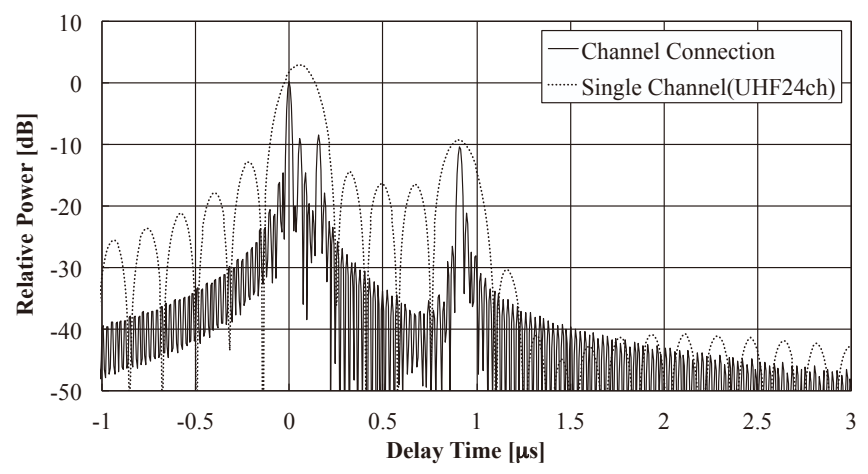

図 13 シミュレーションにおけるチャネル連結後の遅延プロ ファイル (拡大図)

Delay Profile After Performing Channel Connection using Simulated Data(Close-up).

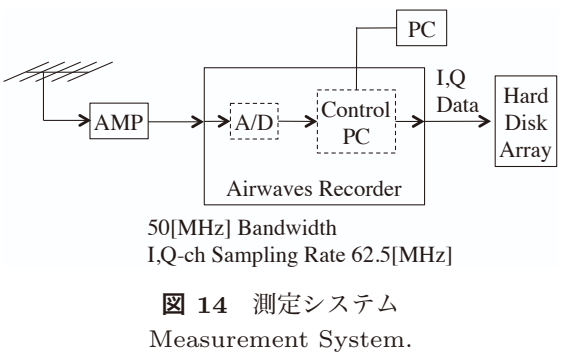

Recorder”は, ”Control PC”により制御が行われる。ま た，アンテナで受信した受信信号に対し中心周波数が $0[\mathrm{~Hz}]$ になるようにダウンコンバージョンを行う。“A/D”では, 同相・直交成分の 2 系統の信号が $62.5[\mathrm{MHz}]$ でサンプリン グされ，それぞれ 16 ビットで量子化される。量子化された 信号は, “Hard Disk Array”に記録される。本測定システ ムでは, 最大 $50[\mathrm{MHz}]$ の有効帯域幅で放送波を記録するこ とができ，ISDB-T信号 8 チャネル分を同時に記録するこ とが可能である。ハードディスクアレイに記録した信号は, コンピュータで任意の処理を行うことが可能である ${ }^{3)}$.

（2）送信局と測定地点

測定システムを用いた測定は, 関東地区で実際に行い, 送 信局である東京タワーの詳細を表 3 , 測定地点の詳細を表 4 に示す。 今回の測定では, 送信局 (東京タワー) において 関東広域を放送対象エリアとしているUHF 带 21 チャネル から 27 チャネルの 7 チャネル分を記録した. 
表 3 送信局の詳細

Parameters of Broadcasting Station.

\begin{tabular}{c|c}
\hline \hline 所在地 & 東京都港区 \\
座標 & $N 35^{\circ} 39^{\prime} 31^{\prime \prime} E 139^{\circ} 44^{\prime} 44^{\prime \prime}$ \\
送信電力 & $10[\mathrm{~kW} / \mathrm{ch}]$ \\
アンテナ高 (海抜高) & $257[\mathrm{~m}](21-24 \mathrm{ch})$ \\
& $267[\mathrm{~m}](25-27 \mathrm{ch})$ \\
\hline
\end{tabular}

表 4 測定地点の詳細

Parameters of Receiving Point.

\begin{tabular}{c|c}
\hline \hline 所在地 & 東京都清瀬市 \\
座標 & $N 35^{\circ} 46^{\prime} 36^{\prime \prime} E 139^{\circ} 31^{\prime} 06^{\prime \prime}$ \\
水平距離 & $24.38[\mathrm{~km}]$ \\
送信局方向 & $122\left[^{\circ}\right]$ (真北を $\left.\left.00^{\circ}\right]\right)$ \\
受信アンテナ高 (海抜高) & $66[\mathrm{~m}]$ \\
\hline
\end{tabular}

（3）測定データのチャネル連結結果

提案方式を実フィールドの測定デー夕に適用し，複数チャ ネルの連結を行い高分解能遅延プロファイルを求めた。各 チャネルにおける周波数オフセットは通常の OFDM 受信機 と同様に補償し ${ }^{13)}$, 各チャネルの伝達特性の推定を行った。

図 15 に実測デー夕から求めた遅延プロファイルを示 す. 図 15 における Relative Power[dB] は, Single Channel(UHF24ch), Channel Connection において, 最も電力 の高い到来波を $0[\mathrm{~dB}]$ とした場合の相対電力 $[\mathrm{dB}]$ を表し ている. 実線が UHF21〜27 チャネル $(518 〜 560[\mathrm{MHz}])$ を 連結して得た遅延プロファイル，破線が UHF 24 チャネル (536〜 542[MHz]) から得た遅延プロファイルを表す．図 16 に図 15 の-1.5〜2.5[ $\mu \mathrm{s}]$ を拡大した遅延プロファイルを示 す。シミュレーション結果の図 10 および図 11 と同様に，7 チャネルの連結により遅延プロファイルの分解能を向上す ることができ, 実測デー夕にも応用が可能である.

\section{4. むすび}

本論文では，地上波デジタルテレビジョン放送の複数チャ ネルを用いることにより周波数帯域幅の拡張を図り遅延時 間分可能を向上させる手法 ${ }^{8)}$ において, 信号带域外の伝達 特性を線形予測フィル夕によって外挿し，外挿された伝達 特性を利用した各チャネルの補正法について提案した。本 提案方式では，信号帯域外の伝達特性を RLS アルゴリズ

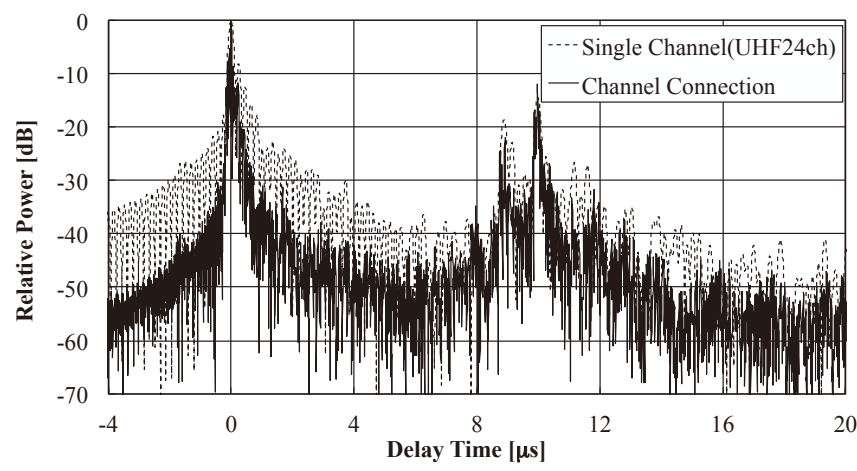

図 15 実測デー夕によるチャネル連結の遅延プロファイル Delay Profile After Performing Channel Connection using Measured Data.

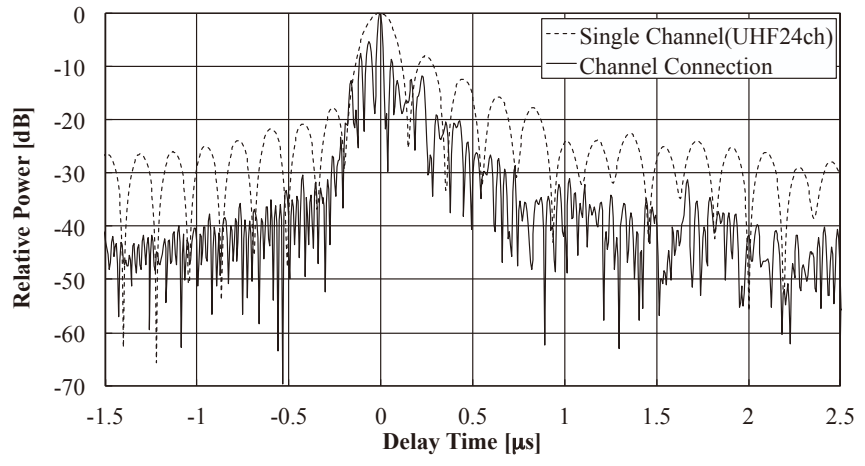

図 16 実測データによるチャネル連結の遅延プロファイル (拡 大図)

Delay Profile After Performing Channel Connection using Measured Data(Close-up).

ムに基づく線形予測フィルタで外挿し，外挿された伝達特 性の重なりを利用し回帰分析を行うことにより，各チャネ ル間の遅延時間差抢よび位相差の補正を行った。また，線 形予測フィルタを用い隣接するチャネル間のガードバンド の補間を行った。本提案方式は，各チャンネルの遅延時間 と位相のみを補正した方式に比べ RMSE を低減すること が可能となり, 遅延プロファイルの分解能を向上させ単一 チャネルでは解析できなかった到来波を分析することが可 能であることがシミュレーションにより確認された。

実フィールドの測定デー夕においても本提案方式を適用 し複数チャネルの連結を行うことにより，シミュレーショ ンと同様な結果を得ることができた。今後は，実測デー夕 についてチャネル連結の有効性について検証したい.さら に，本論文では各チャネルの伝搬経路は同一としてチャネ ル連結を行ったが，各チャネルの伝搬経路が異なっている 場合の影響について検討を行い，各チャネルの周波数オフ セットが遅延プロファイルに与える影響についても検討し たい.

\section{(文献)}

1) “ARIB STD-B31 1.7 版”，電波産業会 (2007)

2) MASAYUKI TAKADA, MASAFUMI SAITO : “Transmission System for ISDB-T”, Proceedings of the IEEE, 94, pp.251-256 (2006)

3）久下孝順, 大野光平，伊丹誠，太田弘毅，菅原浩，熊谷一樹: “SFN-GF の置局検討-マルチパス伝搬解析および反射点の推定に関する検討-”，映 情学技報, BCT2009-72, 33, 32, pp.55-58 (2009)

4）中村聡，生天目翔，久下孝順，大野光平，太田弘毅，伊丹誠: “地上波 デジタル放送におけるマルチパス到来方向測定のための到来時刻推定方 式”，信学技報，WBS2010-07，110，72，pp.35-40 (2010)

5）太田弘毅，伊丹誠: “複数チャネルを連結した伝搬特性解析に関する検 討”, 映情学技報, BCT2009-89, 33, 43, pp.5-8 (2009)

6）太田弘毅，伊丹誠: “複数チャネルの伝達特性を連結した伝搬特性解析伝達特性の連結のための遅延プロファイルの整合に関する検討-”，映情 学技報, BCT2010-41, 34, 14, pp.13-18 (2010)

7）中村聡，生天目翔，久下孝順，大野光平，太田弘毅，伊丹誠: “地上波 デジタル放送における複数チャンネルを用いたマルチパス到来時刻推定 方式”，映情学技報，BCT2010-61，34，33，pp.23-26 (2010)

8）太田弘毅: “複数チャンネルの伝達特性を連結した伝搬特性解析-室内実 験のよる遅延時間分解能に関する検討-”, 映情学技報, BCT2012-60 36. 30, pp.1-4 (2012)

9）池田裕司，吉田晴人，前原文明，高畑文雄：“ガードバンドが存在する OFDM 伝送を対象とした時間領域伝搬路推定法に関する一検討”，信 学技報, RCS2005-101, 105, 356, pp.97-102 (2005)

10）池田裕司，吉田晴人，前原文明，高畑文雄：“ガードバンドが存在す 
る OFDM 伝送を対象とした RLS アルゴリズムに基づく周波数領域 伝搬路推定法に関する一検討”, 信学技報, RCS2005-126, 105, 559, pp.13-18 (2006)

11）池田裕司，吉田晴人，平明徳，前原文明，高畑文雄：“適応フィル夕に よるガードバンドの外扦処理を施した OFDM 用周波数領域伝搬路推定 法”，信学論, J91-B, 4, pp.450-456 (2008)

12）生天目翔，中村聡，久下孝順，大野光平，太田弘毅，伊丹誠: “地上波 デジタル放送におけるマルチパスの到来方向推定のための測定と解析”, 映情学技報，BCT2010-34, 34, 9, pp.13-16 (2010)

13）浜口清：“陸上移動通信用 QAM の複数パイロットシンボルを用いた 周波数オフセット補償方式”，信学論, J79-B, 7, pp.426-428 (1996)

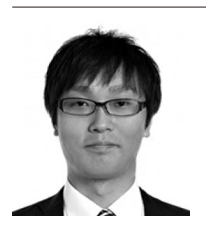

妿柠党 2009 年, 東京理科大学基礎工学部電 子応用工学科卒業. 2011 年, 同大学院基䃈工学研究科電 子応用工学専攻修士課程修了. 現在, 同大学院基䃈工学 研究科電子応用工学専攻博士課程在籍。通信方式，特に OFDM などの研究に従事.

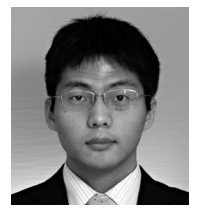

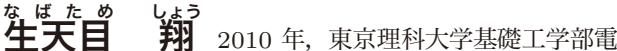
子応用工学科卒業. 2012 年, 同大学院基礎工学研究科電 子応用工学専攻修士課程修了。同年，ソフトバンクモバ イル株式会社 入社、新世代移動体通信方式の研究開発に 従事。現在に至る。正会員

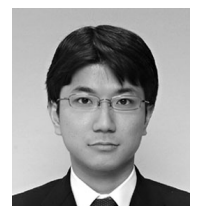

大お野 光光产 2002 年, 明治大学理工学部電子通信 工学科卒業. 2004 年, 同大学大学院理工学研究科博士前 期課程修了. 2007 年, 同大学大学院理工学研究科博士 後期課程修了。同年，東京理科大学基䃈工学部電子応用 工学科助教. 2013 年, 明治大学総合数理学部専任講師。 通信方式，特に広帯域無線技術などの研究に従事。博士 (工学).

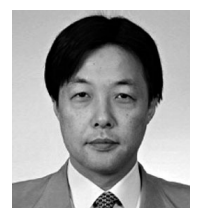

太お志弱秸 1979 年, 東京工業大学付属工業高等学 校電子科卒業。同年, 郵政省電波研究所 (現, 情報通信研 究機構）入所， 1985 年，同放送技術研究室勤務。以来, 地上波デジタルテレビジョン放送などの研究に従事．正 会員.

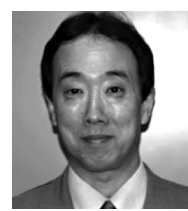

伊丹み 發 1984 年, 東京大学工学部電子工学科 卒業. 1989 年, 同大学大学院工学系研究科電気工学専攻 博士課程修了, 同年, 東京理科大学基䃈工学部電子応用 工学科講師。2000 年, 同大学助教授.2008 年, 同大学教 授. 現在に至る。通信方式, 信号処理, 教育工学などの研 究に従事. 工学博士。正会員。 